\title{
Is the surface topography a helpful tool for the management of scoliosis?
}

\author{
D Papadopoulos
}

From 8th International Conference on Conservative Management of Spinal Deformities and SOSORT 2011 Annual Meeting Barcelona, Spain. 19-21 May 2011

\section{Background}

The aim is to reveal the importance of surface topography in complement to the $\mathrm{x}$-rays $[1,2]$.

\section{Material and methods}

We have used the Formetric 4D-Dicom II system, which is supplied also with lateral Cobb angle measurement. We have examined 616 patients (432 females and 184 males), age $5 \mathrm{y}$ to $21 \mathrm{y}$. The patients have been visited clinically by inspection, Adams forward bending test and Perdriolle scoliometer. We have fit, to every patient, 4-8 reflectors on the apex of $\mathrm{T} 1$ through $\mathrm{L} 4$ spinal process and 2 shoulder reflectors to get the possibility for lateral Cobb angle measurement with the Formetric 4D.

\section{Results}

We had various data through surface topography. Torsion, rotation, shoulder tilt, etc, but we have insisted on the Cobb angle measurement. We had a $>95 \%$ accuracy in Scoliosis between $22^{\circ}$ and $65^{\circ} \mathrm{Cobb}$ angle. The accuracy was lower, between $95 \%$ to $70 \%$, if the measured curve was $>65^{\circ}$ and very poor, less than $50 \%$, when the curve was $<$ than $20^{\circ}$ in $\mathrm{x}$-rays. As it concerns the Kyphosis, the cob angle was very accurate as it was exceeded $90 \%$.

\section{Conclusions}

We believe that the surface topography is a precious tool for the diagnosis and follow up of a complex three dimensional skeletal deformity, such as scoliosis. The accuracy of the Cobb angle measurement is excellent and we believe that we must move to the next step, which is the 3D dimension.

Published: 27 January 2012

SPONDYLOS Laser Spine Lab , Athens, Greece

\section{References}

1. Hackenberg L, Hierholzer E, Liljenqvist U: Accuracy of rasterstereography versus radiography after anterior correction and fusion. Stud Health Technol Inform 2002, 91:241-5.

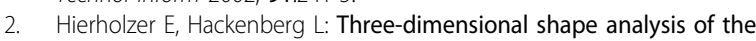
scoliotic spine using MR tomography and rasterstereography. Stud Health Technol Inform 2002, 91:284-9.

doi:10.1186/1748-7161-7-S1-017

Cite this article as: Papadopoulos: Is the surface topography a helpful tool for the management of scoliosis? Scoliosis 2012 7(Suppl 1):017.

Submit your next manuscript to BioMed Central and take full advantage of:

- Convenient online submission

- Thorough peer review

- No space constraints or color figure charges

- Immediate publication on acceptance

- Inclusion in PubMed, CAS, Scopus and Google Scholar

- Research which is freely available for redistribution

\section{Ciomed Central}

(c) 2012 Papadopoulos; licensee BioMed Central Ltd. This is an open access article distributed under the terms of the Creative Commons Attribution License (http://creativecommons.org/licenses/by/2.0), which permits unrestricted use, distribution, and reproduction in any medium, provided the original work is properly cited. 